\title{
A study on variation of atmospheric pollutants over Bhubaneswar during imposition of nationwide lockdown in India for the COVID-19 pandemic
}

\author{
Subhasmita Panda ${ }^{1,2} \cdot$ Chinmay Mallik ${ }^{3} \cdot$ Jyotishree Nath $^{1} \cdot$ Trupti Das $^{1,2} \cdot$ Boopathy Ramasamy $^{1}$ (D)
}

Received: 26 May 2020 / Accepted: 17 August 2020 / Published online: 24 August 2020

(C) Springer Nature B.V. 2020

\begin{abstract}
The nationwide lockdown in India to flatten the pandemic COVID-19 curve has resulted in the reduction of anthropogenic emission sources to a great extent. This study reports change in air quality and its impact on the environment during the unique lockdown scenario at Bhubaneswar, a coastal smart city in east India. The urban air shows a remarkable reduction in the mean pollutant levels influenced by traffic emission viz. $\mathrm{NO}_{\mathrm{x}}(\sim 67 \%)$ and $\mathrm{BC}(\sim 47 \%)$ during lockdown over the pre-lockdown. Comparatively, a lower reduction of $\mathrm{CO}(\sim 14 \%)$ is attributed to the dominance of natural atmospheric chemical regulation and biogenic sources in addition to anthropogenic contributions. In addition to the lockdown, frequent rain events due to depression in the Bay of Bengal (BoB) also had a significant role in the reduction of the primary pollutants over the study site. An enhancement of secondary pollutant viz. $\mathrm{O}_{3}(\sim 3 \%)$ with a distinct diurnal pattern was observed during the first phase of lockdown over the pre-lockdown period. An anti-correlation between $\mathrm{O}_{3}$ and $\mathrm{NO}_{\mathrm{x}}$ during pre-lockdown points to a higher $\mathrm{O}_{3}$ production potential with decreasing $\mathrm{NO}_{\mathrm{x}}$. While a reduction in the titration of $\mathrm{O}_{3}$ due to suppression of fresh $\mathrm{NO}$ emissions led to accumulation of $\mathrm{O}_{3}$ in the first phase of lockdown, inhibited photochemistry due to cloudy skies as well as reduction in precursors led to lower $\mathrm{O}_{3}$ values during the later phases of lockdown.
\end{abstract}

Keywords Lockdown $\cdot$ Air quality $\cdot \mathrm{CO} \cdot \mathrm{NO}_{\mathrm{x}} \cdot \mathrm{BC} \cdot \mathrm{O}_{3}$

\section{Introduction}

The spread of novel coronavirus (COVID-19) was initially identified in Wuhan city of China, in early December 2019, and then was successively transmitted across the world with 4 million cases in the first 4 months. While the first case of the COVID-19 pandemic was confirmed on 31 January 2020 in

Electronic supplementary material The online version of this article (https://doi.org/10.1007/s11869-020-00916-5) contains supplementary material, which is available to authorized users.

Boopathy Ramasamy

chemboopathy@gmail.com; boopathy@immt.res.in

1 Environment \& Sustainability Department, CSIR-Institute of Minerals \& Materials Technology (CSIR-IMMT), Bhubaneswar, Odisha 751013, India

2 Academy of Scientific and Innovative Research (AcSIR), CSIR-Institute of Minerals \& Materials Technology (CSIR-IMMT), Bhubaneswar, India

3 School of Earth Sciences, Department of Atmospheric Science, Central University of Rajasthan, Rajasthan, India
India, it was detected on 16 March 2020 in Odisha, an eastern coastal state in India. The country saw a sudden jump in COVID-19 cases during mid of March (https:/www.mohfw. gov.in/). In order to stem the spread of novel coronavirus, the Indian government called for a 14-h voluntary public curfew called as Janta Curfew on 22 March 2020. Besides, the Odisha Government called for an early lockdown of five districts of the state from 22 March 2020 to 29 March 2020 together with Bhubaneswar $\left(20.30^{\circ} \mathrm{N}, 85.82^{\circ} \mathrm{E}\right)$, the state capital, and a globally acclaimed smart city. However, after 3 days of Janta Curfew, the Indian Government enforced a complete nationwide lockdown for 21 days from 25 March to 14 April 2020 (lockdown 1.0) then extended it further until 03 May 2020 (lockdown 2.0). Thus, the lockdown limited the movement of the entire 1.3 billion population of India in an effort to flatten the infection/transmission curve during the pandemic. Confinement of population, shutting off a large portion of industrial activity, and bringing public transport to a standstill led to a considerable decrease in anthropogenic emissions and, consequently, in the level of urban air pollution. However, essential services such as electricity, water, municipal sanitation bodies, hospitals, banks and financial 
services, shops dealing with food and medicines, and movement of essential goods trucks and trains were exempted from lockdown. With the rising tolls of COVID-19 cases, the Government of India further extended the lockdown two times until 31 May 2020 with some conditional relaxation. Moreover, night curfews were imposed during the entire May (lockdown 3.0 and lockdown 4.0) month from 7 PM to 7 AM. The pandemic outbreak has caused a large economic disruption in India. So, the Indian Government has allowed restarting various industrial and other commercial activities with $50 \%$ of workforce called Unlock-1 during 01 June-30 June 2020 with strict guidelines. However, to tackle the emergency and curb the dispersion of COVID-19, the Odisha Government continued the night curfew from $7 \mathrm{PM}$ to $5 \mathrm{AM}$ with an addition of complete shutdown of weekends during entire June month of 2020.

The sudden change in emissions is expected to have a drastic impact on air quality, and the situation can be used as a natural experiment to simulate the sensitivity of certain pollutants prevailing in ambient air. In this context, air quality parameters such as carbon monoxide (CO), oxides of nitrogen $\left(\mathrm{NO}_{\mathrm{x}}=\mathrm{NO}+\mathrm{NO}_{2}\right)$, black carbon $(\mathrm{BC})$, and ozone $\left(\mathrm{O}_{3}\right)$ are analysed. The measurements were carried out at CSIRInstitute of Minerals and Materials Technology (IMMT) located in the heart of Bhubaneswar city during March-June 2020 (Fig. 1). Bhubaneswar, the capital city of Odisha state in eastern coastal India, is home to more than 8 lakhs people (https://www.census2011.co.in/census/city/270bhubaneswar.html). The city, enlisted in the Government of India smart city program, is undergoing significant development in the construction of roads, shopping malls, residential areas around the city, and the consequent anthropogenic emissions. According to the 2018 RTO database, a total of 76,946 vehicles were registered in the Bhubaneswar city out of which $70 \%$ are personal vehicles.
Furthermore, the city is fenced with numerous point sources of pollution like the thermal power plants, steel plants, cement industries, mines, metallurgical plants, and manufacturing industries in the north and north-west direction and two major shipping harbours, one (Paradeep Port) $\sim 100 \mathrm{~km}$ towards the eastern direction and the other (Dhamra Port) $\sim 159 \mathrm{~km}$ towards the north-eastern part (Mahapatra et al. 2018). Despite nationwide lockdown, the thermal power plants, steel processing industries, mining activities, production and distribution of thermal and coking coal, limestone, dolomite, manganese, and chromite in and around Odisha were operational, as a part of essential services (http://www.ecoti.in/tQMoEb80). However, there was a reduction of $\sim 60 \%$ of production capacity due to a fall in the number of workers.

Apart from this, the study site is considered to be a strategic location as it is a gateway of most of the polluted air mass that reaches the BoB from the Indo Gangetic Plains (IGP), and the heavily industrialised Chotta Nagpur Plateau region as well as the western part of India (Mallik et al. 2019). Therefore, in the current pandemic situation as various phases of lockdown were imposed over this region, it was indeed a unique scenario to understand the behaviour, source, and concentration of primary and secondary ambient air pollutants like $\mathrm{CO}, \mathrm{NO}_{\mathrm{x}}, \mathrm{BC}$, and $\mathrm{O}_{3}$. The data has been presented here to understand the variation of measured pollutants in the perspective of the environment when anthropogenic emissions are curtailed. While $\mathrm{CO}$ can give an insight into both anthropogenic and biogenic emissions together with chemical processing in the atmosphere, $\mathrm{NO}_{\mathrm{x}}$ and $\mathrm{BC}$ can give a direct insight into the emission scenario w.r.t. gas and aerosol phases. Furthermore, $\mathrm{O}_{3}$ variations can give an insight into the photochemical processes operating in the atmosphere. Thus, the primary goal of this study is to evaluate and understand the change in the air quality of the region with a sudden reduction in anthropogenic emissions. The change in emission regime provided an

Fig. 1 Location map pf sampling site in CSIR-IMMT,

Bhubaneswar, Odisha (marked as ' 1 ')

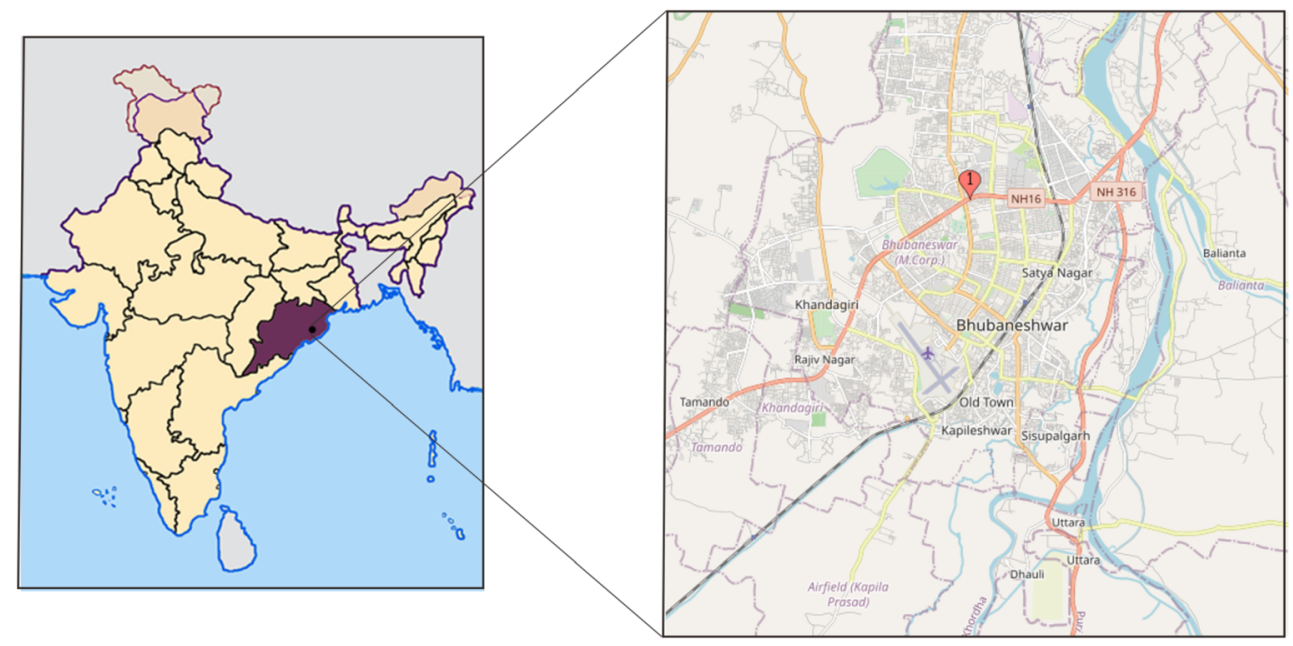


opportunity to generate baseline data for the region, which will help to adopt new strategies to ensure better air quality.

\section{Methodology}

\section{Measurement techniques}

The in situ measurements of near surface $\mathrm{CO}$ was made in Bhubaneswar using an online CO analyser (Horiba, APMA370). The analyser is based on cross modulation-type nondispersive infrared absorption at $4.67 \mu \mathrm{m}$ vibration band and has a detection limit of $50 \mathrm{ppb}$ for a $60 \mathrm{~s}$ response time (Mahapatra et al. 2014a). Simultaneously, the measurement of $\mathrm{NO}_{\mathrm{x}}$ and $\mathrm{O}_{3}$ was carried with a chemiluminescene $\mathrm{NO}_{\mathrm{x}}$ analyser (Thermo fisher scientific, 42i), and UV photometric $\mathrm{O}_{3}$ analyser (Thermo fisher scientific,49i) respectively. The $\mathrm{NO}_{\mathrm{x}}$ analyser works on the principle of chemiluminescence effect produced due to oxidation of $\mathrm{NO}$ by $\mathrm{O}_{3}$ molecule at $630 \mathrm{~nm}$ and has a detection limit of $50 \mathrm{ppt}$ with a response time of $50 \mathrm{~s}$. The $\mathrm{O}_{3}$ analyser works on the principle of absorption of UV radiation by atmospheric $\mathrm{O}_{3}$ at $254 \mathrm{~nm}$. The lower detection limit is $1 \mathrm{ppb}$ with a response time of $20 \mathrm{~s}$. All instruments were periodically calibrated using NIST traceable calibration standards and multi-channel calibrator. The analysers drew ambient air samples in using a 2-m-long polytetrafluoroethylene (PTFE) tubing placed at a height of $20 \mathrm{~m}$ above the ground level. Besides, PTFE filters were placed at the sampling inlet of each analyser to remove dust and larger particles. A more detailed description can be found in Mahapatra et al. (2014a, 2019), Mallik et al. (2019).

In addition, $\mathrm{BC}$ measurements were performed using a seven-channel (370, 470, 520,590, 660, 880, and $950 \mathrm{~nm}$ ) optical wavelength Aethelometer (Magee Scientific, AE33). The instrument was equipped with $2.5-\mu \mathrm{m}$ cut point of $\mathrm{PM}_{2.5}$-cyclone along with a rain/insect guard, and was operated continuously at a flow rate of $2 \mathrm{~L} \mathrm{~min}^{-1}$. The $880-\mathrm{nm}$ wavelength was used to derive the $\mathrm{BC}$ concentration, as described by the previous studies (Babu and Moorthy 2002).

Surface level meteorological parameters viz. temperature (T), rainfall, relative humidity (RH), wind speed (WS), and wind direction (WD) were continuously monitored and recorded during the study period with the help of an Automatic Weather Station (AWS) mounted at the rooftop of CSIR-IMMT.

\section{Analysis of lockdown periods}

This study adopts an intra-comparative approach to analyse the impact of COVID-19 lockdown on the environment during March-June 2020. The study period was divided into the following phases:
- Pre-lockdown (PL: 01-21 March 2020)

- Lockdown 1.0 (L1: 22-14April 2020)

- Lockdown 2.0 (L2: 15April-03May 2020)

- Lockdown 3.0 (L3: 04-17 May 2020)

- Lockdown 4.0 (L4: 18-31 May 2020)

- Unlock 1.0 (UL: 01-30 June 2020)

Furthermore, a weekend shutdown was imposed by the Odisha Government during the unlock period. Hence, the unlock period has been further sub divided into unlock weekdays (UL-WDy) and unlock weekends (UL-WEd).

\section{Results and discussion}

\section{Meteorology}

Meteorology plays a key role in the formation and transport of air pollutants (Bao and Zhang 2020; Yen et al. 2013). Hence, surface T, rainfall, RH, WS, and WD were analysed for the study period. Bhubaneswar experiences a tropical weather condition with a hot and humid climate during the summer months. Figure 2 shows the day to day variation of $\mathrm{T}$ and $\mathrm{RH}$ observed during the study period. The daily mean surface $\mathrm{T}$ varied in the range of $23-32{ }^{\circ} \mathrm{C}$, whereas $\mathrm{RH}$ varied in the range of $63-95 \%$.

A total rainfall of $\sim 11 \mathrm{~mm}$ was recorded during prelockdown days while $\sim 1 \mathrm{~mm}, \sim 32 \mathrm{~mm}$, and $\sim 9 \mathrm{~mm}$ during L1, L2, and L3, respectively (Fig. S1). The increased rain event during the end of April is attributed to a depression in the BoB (Mahapatra et al. 2019; Fadnavis et al. 2011). However, the maximum rain events resulting in $\sim 76 \mathrm{~mm}$ during L4 is due to cyclonic storm "Amphan", which hit Odisha coast on 20 May 2020.

\section{Wind pattern}

The wind rose plot shows the dominance of wind patterns from the south direction indicating the profound influence of marine air mass during the study period (Fig. 3). The 5-daybackward air masses arriving at Bhubaneswar were tracked using NOAA Air Resource Laboratory (ARL) Hybrid SingleParticle Model at $100 \mathrm{~m}$ agl for different phases of the study period (Draxler and Hess 1998; Draxler 1999; Dutkiewicz et al. 2009; Tiwari et al. 2013; Stein et al. 2015) (Fig. S2). Moderate Resolution Imaging Spectroradiometer (MODIS), aboard Aqua, and Terra satellites (C6 version), derived from NASA FIRMS, were used to understand the impact of biomass and crop residue burning over the study site (Giglio et al. 2003, 2016). Fires with $80 \%$ and above detection confidence were only considered to side step any bias due to false fires. Although distinct fire events were observed in central India during L1 and L2, the prevailing air mass mostly of marine 
Fig. 2 Variation in daily average temperature and daily average relative humidity in Odisha during March-June 2020

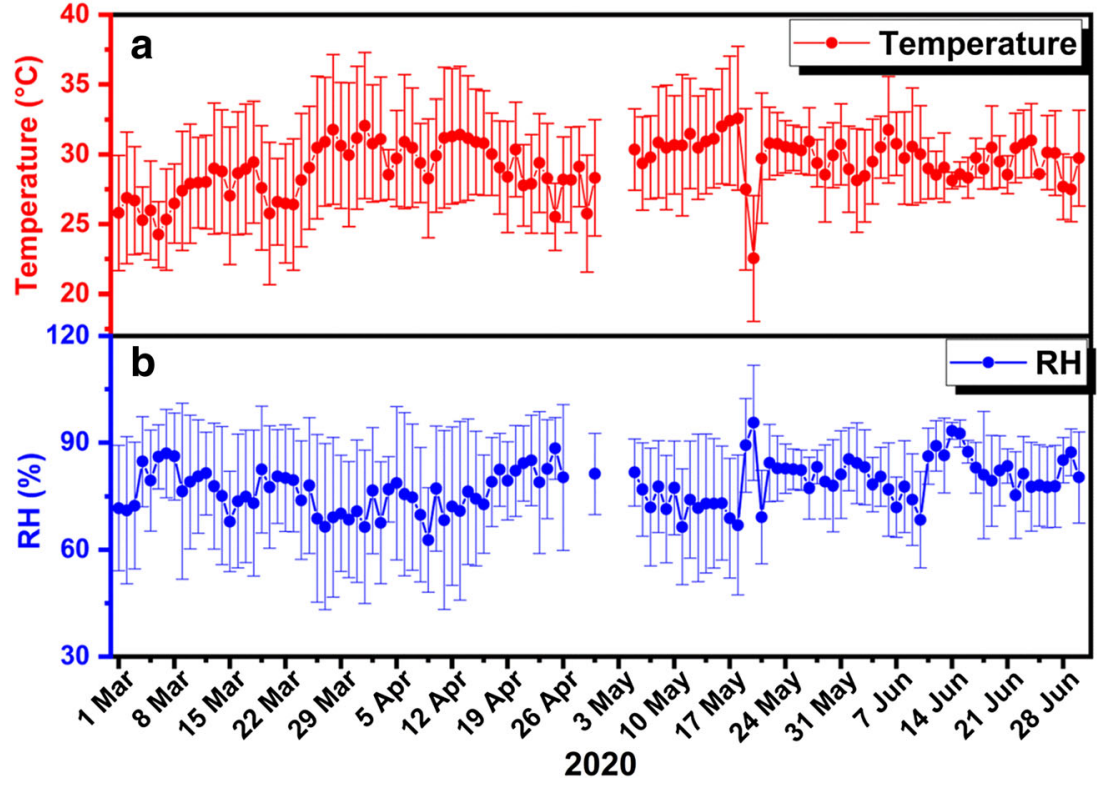

origin indicates the inconsequential impact of regional fire events over the study site (Fig. S2).

\section{Diurnal variability of air pollutants}

The average diurnal variation of surface $\mathrm{CO}, \mathrm{NO}_{\mathrm{x}}, \mathrm{BC}$, and $\mathrm{O}_{3}$ over the study site is shown in Fig. 4. The diurnal variation of $\mathrm{CO}, \mathrm{NO}_{\mathrm{x}}$, and $\mathrm{BC}$ show a bi-modal pattern during PL. The primary pollutants showed a build-up during the morning, and

Fig. 3 Wind rose plot showing local wind direction and distribution of wind speed $(\mathrm{m} / \mathrm{s})$ over the study site (Bhubaneswar) for a March, b April, c May, d June month respectively
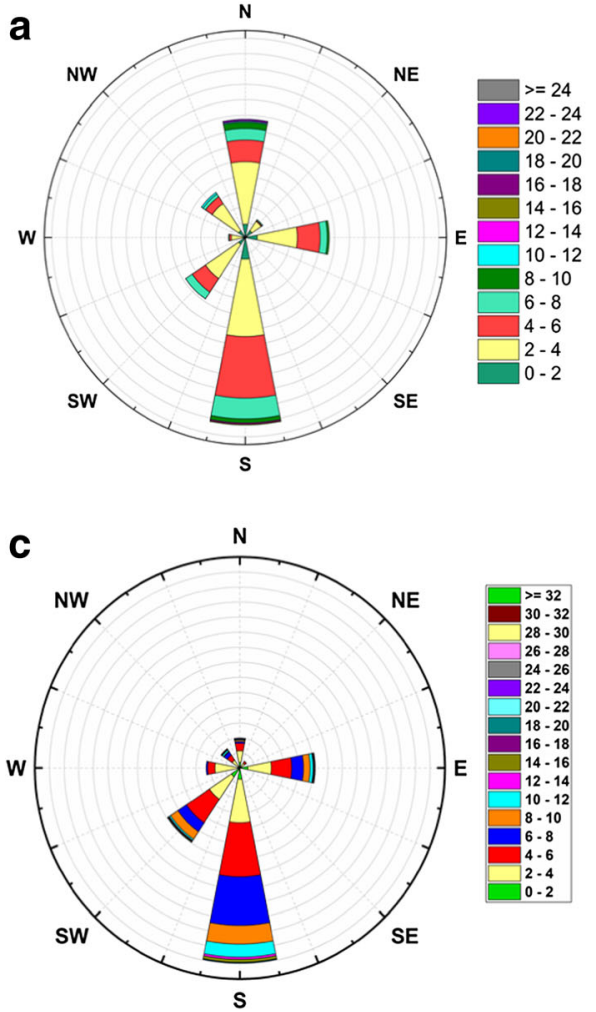

late evening due to an increase in emission sources (mostly traffic-related as the study site situated close to National Highway-16) and suppressed boundary layer that helps trap the pollutants in the lower troposphere. Conversely, higher dilution leads to lower value of these species during noon (Nair et al. 2002; David and Nair 2011). Furthermore, photochemical consumption of $\mathrm{NO}_{\mathrm{x}}$ and $\mathrm{CO}$ also results in their lower value during the daytime. Previous reports also observed a distinct bi-modal peak in almost all the seasons for 
CO, $\mathrm{NO}_{\mathrm{x}}$ (Xie et al. 2016; Zhao et al. 2016; Yadav et al. 2016; Jang et al. 2017; Zheng et al. 2017), and BC (Babu et al. 2002; Beegum et al. 2009; Mahapatra et al. 2014b; Kompalli et al. 2014; Talukdar et al. 2015; Vaishya et al. 2017; Rana et al. 2019) depicting the influence of anthropogenic emissions in urban areas. In addition, analysis of tropospheric $\mathrm{CO}$ by Ghude et al. (2011) and Girach and Nair (2014) over Indian subcontinent have revealed that $\mathrm{CO}$ emissions in eastern India is mostly dominated by coal combustion from the thermal power plants along with biofuel and biomass burning. However, during the current lockdown phases, we could not observe prominent bi-modal peaks for $\mathrm{CO}, \mathrm{NO}_{\mathrm{x}}$, and $\mathrm{BC}$. Thus, the suppressed rush hour peaks for three pollutants is a direct indication of lockdown effects, and such suppression have not been observed during similar time periods in previous years over the study site (Mahapatra et al. 2014a, b). The suppressed peaks for $\mathrm{CO}$ and $\mathrm{NO}_{\mathrm{x}}$ during the various lockdown phases can be attributed to curtailment in vehicular movements. Furthermore, for species like $\mathrm{NO}_{\mathrm{x}}$, which have strong local sources and short residence times, the reduction is much more drastic with high pre-lockdown to lockdown ratios compared to a pollutant like $\mathrm{CO}$ with regional sources and a much longer residence time (more than 30 times that of $\mathrm{NO}_{\mathrm{x}}$ ). Similarly, the residence time of $\mathrm{BC}$ of a few days to a week is intermediate between $\mathrm{NO}_{\mathrm{x}}$ and $\mathrm{CO}$, and hence $\mathrm{BC}$ can provide a wider coverage compared to $\mathrm{NO}_{\mathrm{x}}$ in terms of source contributions. The lifetimes of these pollutants are in the order $\mathrm{CO}>\mathrm{BC}>\mathrm{NO}_{\mathrm{x}}$. The L1/PL values for these gases are $0.98,0.73$, and 0.32 , respectively. Likewise, Jain and Sharma (2020) also highlighted a statistically significant plummet in $\mathrm{NO}_{2}(\sim 51 \%)$ in five megacities of India viz. Delhi, Mumbai, Chennai, Kolkata, and Bangalore. However, unlike the pollutants discussed above, the diurnal pattern of surface $\mathrm{O}_{3}$ shows a distinct noon peak during PL and L1 (Fig. 4a), a notable feature of an urban region (Lal et al. 2000; Nishanth et al. 2012; Gaur et al. 2014; Yadav et al. 2016). The $\mathrm{O}_{3}$ concentration starts building up immediately after sunrise, attains maximum value (PL, $30 \mathrm{ppbv}$; L1, $34 \mathrm{ppbv}$ ) during noontime, and then decreases. The daytime increase in concentration is attributed to the photo-oxidation of precursor gases such as $\mathrm{CO}, \mathrm{CH}_{4}$, and NMHCs in the presence of $\mathrm{NO}_{\mathrm{x}}$ (Lal et al. 2000). However, lower $\mathrm{O}_{3}$ concentration during the night is due to inhibition of photochemistry, titration of $\mathrm{O}_{3}$ by surface emissions of $\mathrm{NO}$, and loss due to surface deposition (Mallik et al. 2015). The pronounced elevated diurnal pattern during L1 suggests a higher rate of photochemical production of $\mathrm{O}_{3}$ from precursors compared to $\mathrm{O}_{3}$ destruction (Resmi et al. 2020). The $\mathrm{O}_{3}$ chemistry during $\mathrm{L} 1$ could be due to locally/regionally emitted precursors along with atmospheric transport from the Chota-Nagpur region and the north-western parts of Odisha state (Fig. S2). This is evinced by very similar background concentration observed during night time in PL and lockdown periods. A cloudy sky due to rain events (Fig.
S1) on several days during L2, L3, L4, and UL along with reduced precursor levels inhibits photochemical production of $\mathrm{O}_{3}$ leading to the suppressed diurnal variation of $\mathrm{O}_{3}$ (Ghosh et al. 2015). Furthermore, the standard deviation (SD) in $\mathrm{O}_{3}$ values during the current study is of the order of less than $20 \%$ while the year to year changes in $\mathrm{O}_{3}$ is of the order of $36-45 \%$, implying the impacts of lockdown (Table 1).

\section{Day-to-day variability of air pollutants}

The daily $(24 \mathrm{~h})$ averaged temporal variation of air pollutants viz., $\mathrm{CO}, \mathrm{NO}_{x}, \mathrm{BC}$, and $8 \mathrm{~h}$ averaged surface $\mathrm{O}_{3}$ are shown in Fig. 5. An overall average reduction of $\sim 14 \%, \sim 67 \%, \sim 47 \%$, and $\sim 14 \%$ for $\mathrm{CO}, \mathrm{NO}_{\mathrm{x}}, \mathrm{BC}$, and $\mathrm{O}_{3}$ respectively, are observed during the entire lockdown phase, compared to the prelockdown period. However, the decline in the concentration of pollutant level in the UL period is attributed to change in meteorology due to the onset of monsoon. The minimum, maximum, mean, and standard deviation of the pollutants during different study phases are summarised and presented in Table 1.

The mean $\mathrm{CO}$ and $\mathrm{BC}$ levels show a notable reduction from $\mathrm{L} 1\left(\mathrm{CO}, 526.95 \pm 136.19 \mathrm{ppbv} ; \mathrm{BC}, 1.31 \pm 0.34 \mu \mathrm{g} \mathrm{m}^{-3}\right)$ to L4 (CO, $368.24 \pm 131.44$ ppbv; BC, $0.93 \pm 0.37 \mu \mathrm{g} \mathrm{m}^{-3}$ ), revealing a change of $\sim 30 \%$ and $29 \%$ respectively. However, a two-sample $t$ test shows an insignificant $(p>0.8)$ decline in the concentration of CO during L1 as compared to PL. CO is released during incomplete combustion processes viz. burning of fossil fuel, biomass, garbage as well as from photooxidation of methane $\left(\mathrm{CH}_{4}\right)$, and other hydrocarbons (Fishman and Seiler 1983; Cros et al. 1988; Mahata et al. 2018). Furthermore, the ozone monitoring instrument (OMI) time series of area-averaged methane $\left(\mathrm{CH}_{4}\right)$ mole fraction in the air for March-June 2020 over $20-21^{\circ} \mathrm{N}, 85-86^{\circ} \mathrm{E}$ (https://giovanni.gsfc.nasa.gov/giovanni/) shows no substantial change in $\mathrm{CH}_{4}$ concentration during the observation period (Fig. S3). This can be attributed to the much longer lifetime for $\mathrm{CH}_{4}$ and sources like agriculture, waste, biomass, and biofuel as well as natural sources, making a much larger contribution to $\mathrm{CH}_{4}$ emissions compared to fossil fuels (Bousquet et al. 2011; Saunois et al. 2016; Kavitha et al. 2018). All these sources in and around Bhubaneswar might result in a build-up of $\mathrm{CO}$ concentration during L1. Furthermore, $\mathrm{CO}$ has a longer lifetime due to a combination of $\mathrm{CO}$ production and loss chemistry, being controlled by $\mathrm{OH}$ radical, which is mostly well buffered (Mallik et al. 2018). Nonetheless, a significant reduction in mean CO during L2 over PL could be due to the extended lockdown phase, across the entire country, resulting in a continuous fall in anthropogenic emissions over the study region. $\mathrm{CO}$ concentration decreased further from $219.29 \pm 66.62 \mathrm{ppbv}$ during weekdays to $177.29 \pm 66.62 \mathrm{ppbv}$ during the weekend of UL period due to the imposed curfews, along with the change 
Table 1 Statistics of measured $\mathrm{O}_{3}, \mathrm{NO}_{\mathrm{x}}, \mathrm{CO}$ and $\mathrm{BC}$ during

March-April 2020 at

Bhubaneswar (PL, pre-lockdown;

L1, lockdown 1.0; L2, lockdown

2.0; L3, lockdown 3.0; L4, lock-

down 4.0; UL, unlock 1.0)

\begin{tabular}{|c|c|c|c|c|}
\hline \multicolumn{5}{|c|}{$\mathrm{CO}$ (ppbv) } \\
\hline Phases (date 2020) & Minimum & Maximum & Mean & SD \\
\hline PL $(01 / 3-21 / 3)$ & 367.08 & 660.85 & 535.41 & 84.74 \\
\hline L1 (22/3-14/4) & 276.06 & 837.67 & 526.95 & 133.19 \\
\hline L2 $(15 / 4-03 / 5)$ & 219.07 & 620.42 & 445.44 & 101.47 \\
\hline L3(04/5-17/5) & 198.13 & 673.96 & 493.41 & 126.08 \\
\hline L4 (18/5-31/5) & 178.54 & 527.71 & 368.24 & 131.44 \\
\hline $\mathrm{UL}(01 / 6-30 / 6)$ & 93.54 & 395.00 & 208.09 & 64.41 \\
\hline Weekday during UL & 93.54 & 395.00 & 219.29 & 66.62 \\
\hline Weekend during UL_shutdown & 99.77 & 252.50 & 177.29 & 66.62 \\
\hline \multicolumn{5}{|c|}{$\mathrm{NO}_{\mathrm{x}}(\mathrm{ppbv})$} \\
\hline & Minimum & Maximum & Mean & SD \\
\hline PL (01/3-21/3) & 8.63 & 25.49 & 16.00 & 5.08 \\
\hline L1 (22/3-14/4) & 2.57 & 10.86 & 5.13 & 1.96 \\
\hline L2 (15/4-03/5) & 2.72 & 7.38 & 4.58 & 1.33 \\
\hline L3 $(04 / 5-17 / 5)$ & 3.33 & 9.31 & 5.61 & 1.65 \\
\hline L4 (18/5-31/5) & 1.54 & 15.55 & 5.97 & 4.56 \\
\hline $\mathrm{UL}(01 / 6-30 / 6)$ & 0.97 & 7.39 & 3.44 & 1.72 \\
\hline Weekday during UL & 1.51 & 7.39 & 3.88 & 1.55 \\
\hline Weekend during UL_shutdown & 0.96 & 5.35 & 2.23 & 1.55 \\
\hline \multicolumn{5}{|c|}{$\mathrm{BC}\left(\mu \mathrm{g} \mathrm{m}^{-3}\right)$} \\
\hline & Minimum & Maximum & Mean & SD \\
\hline PL (01/3-21/3) & 0.84 & 2.83 & 1.79 & 0.51 \\
\hline L1 (22/3-14/4) & 0.86 & 2.09 & 1.31 & 0.33 \\
\hline L2 (15/4-03/5) & 0.45 & 1.17 & 0.75 & 0.19 \\
\hline L3 (04/5-17/5) & 0.56 & 1.36 & 0.85 & 0.24 \\
\hline L4 (18/5-31/5) & 0.68 & 2.06 & 0.93 & 0.37 \\
\hline UL $(01 / 6-30 / 6)$ & 0.62 & 2.04 & 1.11 & 0.33 \\
\hline Weekday during UL & 0.64 & 2.04 & 1.16 & 0.34 \\
\hline Weekend during UL_shutdown & 0.62 & 1.48 & 1.01 & 0.34 \\
\hline \multicolumn{5}{|c|}{$\mathrm{O}_{3}(\mathrm{ppbv})$} \\
\hline & Minimum & Maximum & Mean & SD \\
\hline PL (01/3-21/3) & 20.86 & 32.76 & 27.45 & 3.53 \\
\hline L1 (22/3-14/4) & 21.06 & 40.15 & 28.34 & 5.46 \\
\hline L2 $(15 / 4-03 / 5)$ & 17.70 & 24.44 & 21.10 & 2.11 \\
\hline L3 $(04 / 5-17 / 5)$ & 19.02 & 30.58 & 21.88 & 2.86 \\
\hline L4 (18/5-31/5) & 16.95 & 28.34 & 22.83 & 3.84 \\
\hline $\mathrm{UL}(01 / 6-30 / 6)$ & 17.23 & 34.06 & 22.15 & 3.91 \\
\hline Weekday during UL & 17.23 & 34.05 & 21.70 & 3.84 \\
\hline Weekend during UL_shutdown & 18.01 & 29.42 & 23.39 & 3.84 \\
\hline
\end{tabular}

in seasonal meteorology, i.e., transition between pre-monsoon to, monsoon season. $\mathrm{CO}$ and $\mathrm{NO}_{\mathrm{x}}$, which share many common anthropogenic emission sources (Mallik et al. 2015) were found to be weakly associated $(r=0.4)$ over Bhubaneswar (Fig. 6). The low $\mathrm{CO} / \mathrm{NO}_{\mathrm{x}}$ values imply the predominance of vehicular emissions compared to point sources which corroborated by a significant reduction of $\mathrm{NO}_{\mathrm{x}}$ level during the lockdowns.
However, there is a notable reduction of $\sim 47 \%$ in $\mathrm{BC}$ during the entire lockdown as compared to PL. This could be due to curtailment of vehicular emission, which is considered to be dominant source over the study site (Mahapatra et al. 2014b). The BC concentration during UL weekdays $\left(1.16 \pm 0.34 \mathrm{\mu g} \mathrm{m}^{-3}\right)$ was observed to slightly increase in comparison to $\mathrm{L} 4$ due to relaxation in vehicle movement during daytime (7 AM to $7 \mathrm{PM}$ ); however, a slight decrease in $\mathrm{BC}$ 
Fig. 4 Diurnal variation of a surface $\mathrm{CO}, \mathbf{b}$ surface $\mathrm{NO}_{\mathrm{x}}, \mathbf{c} \mathrm{BC}$, and $\mathbf{d}$ surface $\mathrm{O}_{3}$ during prelockdown, lockdown1.0, lockdown 2.0, lockdown 3.0, lockdown 4.0, and unlock-1 at Bhubaneswar

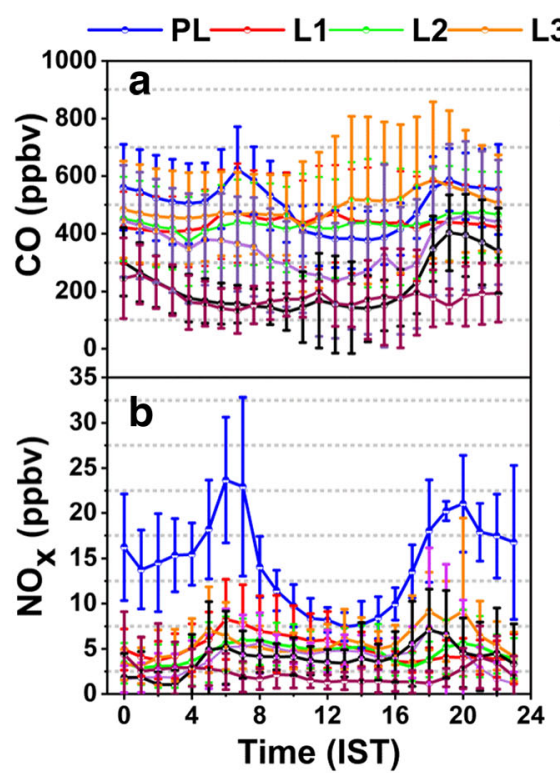

$\left(1.01 \pm 0.34 \mu \mathrm{g} \mathrm{m}^{-3}\right)$ concentration during weekend is due to the imposition of weekends curfew.

During the study period, there was a transport of air masses exclusively from the marine region (Fig S2). It has been reported that pollutants like $\mathrm{CO}$ and $\mathrm{BC}$ are also evinced over the Indian Ocean due to the coastal anthropogenic activities (Girach et al. 2020; Venkataraman et al. 2005). Hence, there is a chance of regional transport of $\mathrm{CO}$ and $\mathrm{BC}$ to the study site through the marine air masses in regions between the coast and the southern site of the measurement location (Fig. S2). These regions include residential areas within Bhubaneswar city as well as slums and villages on the outskirts of the city all the way up to the coast. All these regions will have some activities related to $\mathrm{CO}$ emissions like biomass and garbage burning, brick kilns, and ancillary activities. Assuming an average wind speed of $10 \mathrm{~m} / \mathrm{s}$, an air parcel would take about $16 \mathrm{~h}$ to reach from Puri (or the coast) to Bhubaneswar, covering a distance of $60 \mathrm{~km}$. This travel time is much lower than the lifetime of $\mathrm{NO}_{\mathrm{x}}$ ( $\tau<2$ days), $\mathrm{BC}$ ( $\tau<7$ days), as well as longer lived $\mathrm{O}_{3}$ and $\mathrm{CO}$. Thus, despite being southerly in direction, the winds can still carry the impact of continental emissions to the vicinity of Bhubaneswar. However, the study site witnessed several rain events over the region for the entire L2 phase (Fig. S1), which could have resulted in wet scavenging of pollutants like $\mathrm{O}_{3}$ and $\mathrm{BC}$, and hence the reduction in pollutant concentration was quite prominent during the L2 phase.

A $t$ test shows an insignificant overall increment of $\sim 3 \%$ ( $p$ $>0.2$ ) for $\mathrm{O}_{3}$ in low $\mathrm{NO}_{\mathrm{x}}$ conditions during $\mathrm{L} 1$ as compared to $\mathrm{PL}$ (Fig. 4). The mean $\mathrm{O}_{3}$ value was $27.45 \pm 3.64$ ppbv during
Fig. 5 Temporal variation of a $\mathrm{CO}$ and $\mathrm{BC} \mathbf{b} \mathrm{NO}_{\mathrm{x}}$ and $\mathrm{O}_{3}$ during pre-lockdown, lockdown 1.0, lockdown 2.0, lockdown 3.0, lockdown 4.0, and unlock-1 (March-June 2020) at Bhubaneswar. The blue-coloured background portion represents imposition of night curfew between $7 \mathrm{PM}$ and $7 \mathrm{AM}$ while the yellow-coloured background portion represents imposition of night curfew between 9 PM and 5 AM.The small boxes represent minimum concentration gases observed during the study period

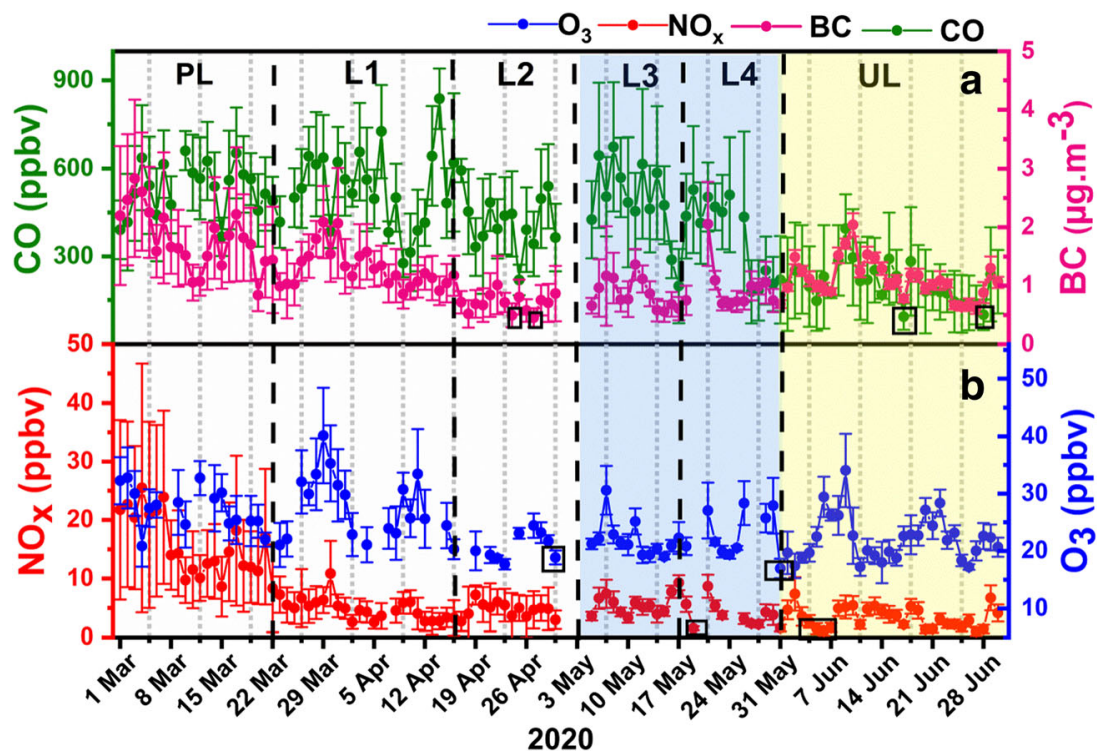



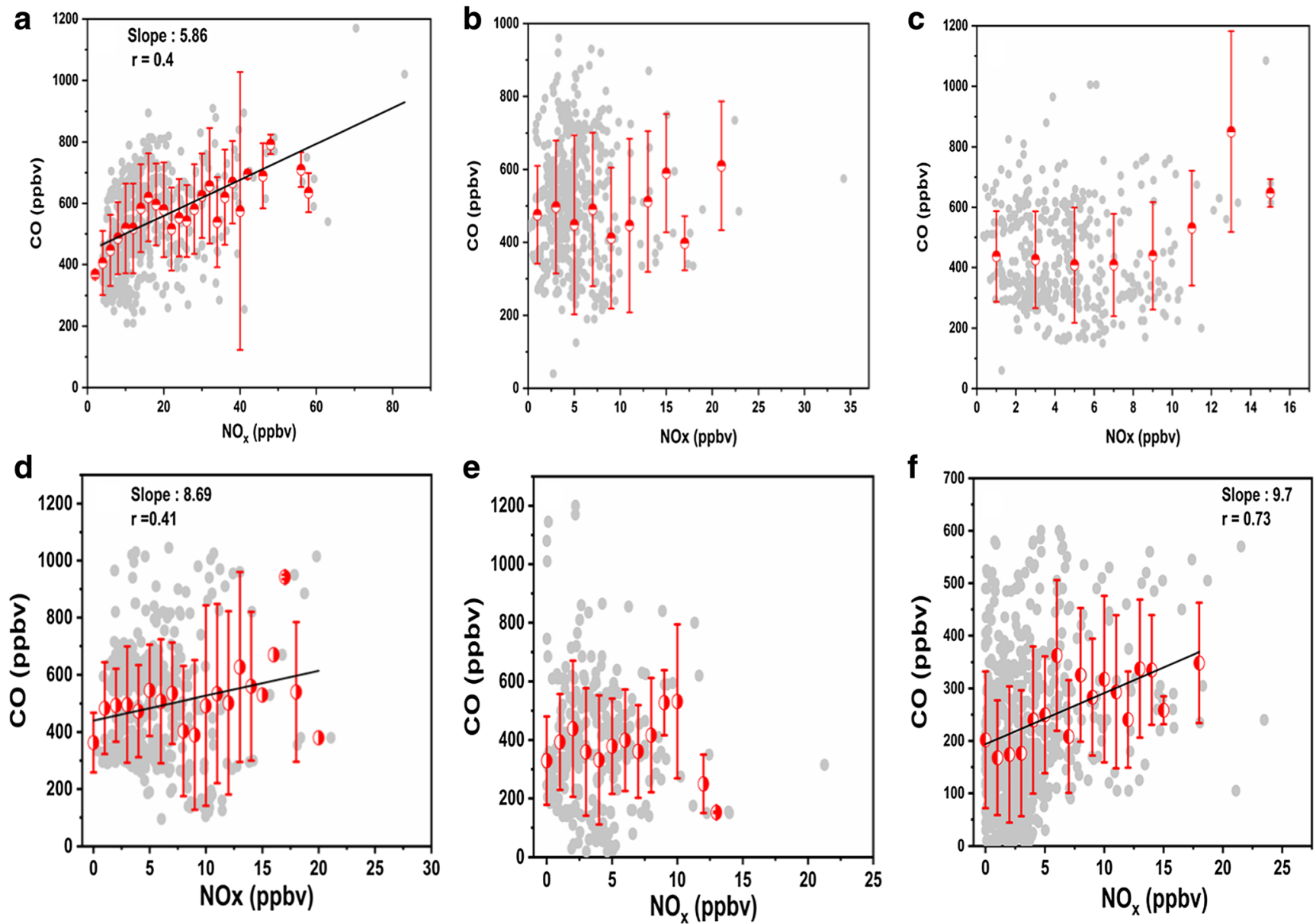

Fig. 6 Relationship of $\mathrm{CO}$ and $\mathrm{NO}_{\mathrm{x}}$ over Bhubaneswar during a pre-lockdown, b lockdown 1.0, $\mathbf{c}$ lockdown 2.0, d lockdown 3.0, e lockdown 4.0, and $\mathbf{f}$ unlock-1

$\mathrm{PL}$, which rises to $28.33 \pm 5.63 \mathrm{ppbv}$ during L1. An enhancement in the $\mathrm{O}_{3}$ level during $\mathrm{L} 1$ with favourable meteorological conditions was also observed in other parts of eastern India (Sharma et al. 2020b) along with Barcelona, Spain (Tobias et al. 2020), and China (Huang et al. 2020). Similarly, $\mathrm{O}_{3}$ concentration was found to be higher during lockdown (25 March-17 May 2020) as compared to before lockdown (1020 March 2020) in five major cities of Rajasthan (Sharma et al. 2020a). However, apart from L1, the concentration of $\mathrm{O}_{3}$ is lower than the PL concentration. Likewise, Sharma et al. (2020b) reported diminution of $\mathrm{O}_{3}$ concentration in the western, northern, and southern regions of India during the lockdown phases.

The photochemical chain reaction which produces $\mathrm{O}_{3}$ is controlled by complex non-linear chemistry (Seinfeld and Pandis 1998; Tiwari et al. 2015) as represented in equations (1) to (3):

$\mathrm{NO}_{2}+\mathrm{hv} \rightarrow \mathrm{NO}+\mathrm{O}^{*}$

$\mathrm{O}_{2}+\mathrm{O}^{*} \rightarrow \mathrm{O}_{3}$
$\mathrm{O}_{3}+\mathrm{NO} \rightarrow \mathrm{NO}_{2}+\mathrm{NO}$

Henceforth, it is evident from the above equations that $\mathrm{NO}_{\mathrm{x}}$ concentrations significantly control $\mathrm{O}_{3}$ photochemistry. Several previous studies over the Indian subcontinent revealed that vehicular emissions are the major source of $\mathrm{NO}_{\mathrm{x}}$ (Aggarwal and Jain 2015; Jain et al. 2016). Recently, Singh and Chauhan (2020) also reported a significant reduction in tropospheric $\mathrm{NO}_{2}$ over eastern India during lockdown as compared to the same period of 2019. Similarly, Xu et al. (2020) reported a significant reduction in primary pollutants due to lockdown in Hubei Province, Wuhan, Jigmen, and Enshi in Central India. Hence, a prominent reduction of $\sim 65 \%$ in $\mathrm{NO}_{\mathrm{x}}$ during $\mathrm{L} 1$ compared to PL over the study site facilitates $\mathrm{O}_{3}$ accumulation in the urban atmosphere. However, a lack of precursor transport mediated by cleaner marine air masses and cloudy sky due to frequent rain events during L2, L3, $\mathrm{L} 4$, and $\mathrm{UL}$ reduced $\mathrm{O}_{3}$ production over the study site. Fig. $\mathrm{S} 4$ shows the daytime relationship between $\mathrm{O}_{3}$ and $\mathrm{NO}_{x}$ during the six different lockdown phases. An anti-correlation $(r=$ -0.75 ) between $\mathrm{O}_{3}$ and $\mathrm{NO}_{x}$ during PL (Fig. S4a) is attributed to an increase in $\mathrm{O}_{3}$ concentration during daytime due to 
Table 2 Comparison of Inter-annual $\mathrm{BC}, \mathrm{CO}$ and $\mathrm{O}_{3}$ concentration for the period of April and May at Bhubaneswar

\begin{tabular}{|c|c|c|c|c|c|c|c|c|c|}
\hline \multirow{2}{*}{$\begin{array}{l}\text { Pollutant } \\
\text { Years/period of } \\
\text { observation }\end{array}$} & \multicolumn{3}{|l|}{$\mathrm{CO}$ (ppbv) } & \multicolumn{3}{|l|}{$8 \mathrm{~h} \mathrm{O}_{3}$ (ppbv) } & \multicolumn{3}{|c|}{$\mathrm{BC}\left(\mu \mathrm{g} \mathrm{m}^{-3}\right)$} \\
\hline & 2014 & 2020 & $\begin{array}{l}\% \\
\text { change }\end{array}$ & 2014 & 2020 & $\begin{array}{l}\% \\
\text { change }\end{array}$ & 2015 & 2020 & $\begin{array}{l}\% \\
\text { change }\end{array}$ \\
\hline April & $553.10 \pm 187.68$ & $474 \pm 154.91$ & $(-) 14.3$ & $42.7 \pm 9.2$ & $23.4 \pm 5.47$ & $(-) 45.18$ & $1.94 \pm 0.57$ & $0.95 \pm 0.29$ & (-) 51.03 \\
\hline May & $407.40 \pm 116.96$ & $439.7 \pm 196.94$ & (+) 7.9 & $34.7 \pm 10.49$ & $22.2 \pm 2.11$ & $(-) 36.15$ & $1.91 \pm 0.41$ & $0.87 \pm 0.31$ & (-) 54.45 \\
\hline
\end{tabular}

photochemical production and decrease in $\mathrm{NO}_{\mathrm{x}}$ due to photochemical decomposition as well as boundary layer dilution (Lal et al. 2014; Ghosh and Sarkar 2016). The titration of $\mathrm{O}_{3}$ at higher $\mathrm{NO}_{\mathrm{x}}$ levels during $\mathrm{PL}$ was not observed during the lockdown periods (Fig. S4 b \& c). Nonetheless, a lack of correlation between $\mathrm{O}_{3}$ and $\mathrm{NO}_{\mathrm{x}}$ during lockdown (Fig. S4 b, c, d \& e) indicates $\mathrm{O}_{3}$ chemistry is complex, and its production does not simply increase with $\mathrm{NO}_{\mathrm{x}}$ reduction. During $\mathrm{L} 1$, the enhancement in $\mathrm{O}_{3}$ concentration in low $\mathrm{NO}_{\mathrm{x}}$ emission might be due to a change in volatile organic carbon (VOC) and $\mathrm{NO}_{\mathrm{x}}$ ratio. However, in the absence of concomitant measurements of VOC, it is not possible to estimate the exact production potential of $\mathrm{O}_{3}$.

We also made an attempt to compare the complete lockdown period (April-May 2020) pollution scenario with the available data for the same period of previous years. The mean and sigma of $\mathrm{CO}, \mathrm{O}_{3}$, and $\mathrm{BC}$ for different periods of observation are presented in Table 2 . Immediate previous years (2016-2019) for all the pollutants were not available, so we compared the measurements during 2014-2015, when these measurements are available for $\mathrm{O}_{3}, \mathrm{CO}$, and BC. There was a more than $40 \%$ reduction in $\mathrm{O}_{3}$ and $50 \%$ reduction in $\mathrm{BC}$ concentration of the current period (2020) in comparison to the same period of the previous years of observation. The 1-sigma standard deviations of these gases during the lockdown period are much less compared to the year-to-year variation (Table 2). This supports the fact that apart from local/regional meteorology, the various lockdown phases had a significant effect in bringing about a reduction in the concentration of various primary as well as secondary pollutants. The overall reduction in $\mathrm{O}_{3}$ can be attributed to lower precursor levels, also impacted by the lower amount of transported precursors as well as inhibiting meteorological conditions like rain events and cloud cover. Interestingly, we did not observe as much reduction in $\mathrm{CO}$ as it is emitted through both anthropogenic and biogenic sources, and its lifetime is intrinsically related to the chemical processing in the atmosphere. Even during the complete lockdown phase during April-May 2020, biofuel emissions could be significantly active for cooking purposes (in the city slums as well as in the surrounding villages). Furthermore, $\mathrm{OH}$ radical, the main chemical scavenger of $\mathrm{CO}$, is mostly well buffered in $\mathrm{NO}_{\mathrm{x}}$ ranges encountered during the study period (Mallik et al. 2018).

\section{Conclusion}

The extent of change in air quality is studied over Bhubaneswar, an urban city in eastern India, during an unprecedented nationwide lockdown scenario. A significant reduction of primary pollutants, like $\mathrm{NO}_{\mathrm{x}}(\sim 67 \%)$ and $\mathrm{BC}(\sim$ $47 \%$ ) reveals that a reduced traffic pollution and essential anthropogenic activities led to better air quality during lockdown periods. There was a more than $40 \%$ reduction in $\mathrm{O}_{3}$ and a $50 \%$ reduction in $\mathrm{BC}$ concentration of the current period (2020) in comparison to the same period of the previous years. This supports the fact that apart from local/regional meteorology, the various lockdown phases had a significant effect in bringing about a reduction in the concentration of various primary as well as secondary pollutants. The overall reduction in $\mathrm{O}_{3}$ was attributed to lower precursor levels, as well as inhibiting meteorological conditions like rain events and cloud cover. Among $\mathrm{CO}, \mathrm{NO}_{\mathrm{x}}, \mathrm{BC}$, and $\mathrm{O}_{3}, \mathrm{CO}$ was the least impacted from the lockdown due to lower contribution of fossil fuels to $\mathrm{CO}$ sources and a much longer atmospheric lifetime mediated by natural chemical processing in the atmosphere. The nationwide lockdown has provided a unique opportunity for the researchers and policymakers to take a closer look at the impact of emission reductions on air quality and develop balanced mitigation strategies for controlling multiple pollutants.

Acknowledgements The authors are thankful to the Director, CSIRIMMT and the Head, Environment and Sustainability Department, CSIR-IMMT for their encouragement. TD and BR are grateful to ISRO-GBP (ATCTM \& ARFI) for the financial support. We thank two anonymous reviewers for their valuable suggestions and comments which helped us to improve the manuscript.

Authors' contributions Subhasmita Panda: original draft, methodology, data analyses, review and editing. Chinmay Mallik: methodology, data analyses, investigation, review and editing. Jyotishree Nath: methodology, data curation. Trupti Das: writing, investigation, review and editing, 
supervision, funding acquisition. Boopathy Ramasamy: review and editing, visualization, investigation, funding acquisition.

Funding information This work was financially supported by Indian Space Research organisation-Geosphere biosphere programme (ISROGBP).

Data availability The datasets used and/or analysed during the current study are available with the corresponding author, and can be obtained upon reasonable request.

\section{Compliance with ethical standards}

Competing interests The authors declare that they have no known competing interests.

\section{References}

Aggarwal P, Jain S (2015) Impact of air pollutants from surface transport sources on human health: a modeling and epidemiological approach. Environ Int 83:146-157. https://doi.org/10.1016/j.envint.2015.06.010

Babu SS, Moorthy KK (2002) Aerosol black carbon over tropical coastal station in India. Geophys Res Lett 29(23):131-134. https://doi.org/ 10.1029/2002GL015662

Babu S, Satheesh SK, Krishna Moorthy K (2002) Aerosol radiative forcing due to enhanced black carbon at an urban site in India. Geophys Res Lett 29(18):271-274. https://doi.org/10.1029/2002GL015826

Bao R, Zhang A (2020) Does lockdown reduce air pollution? Evidence from 44 cities in northern China. Sci Total Environ 731:139052. https://doi.org/10.1016/j.scitotenv.2020.139052

Beegum SN, Moorthy KK, Babu SS, Satheesh SK, Vinoj V, Badarinath KVS, Safai PD, Devera PCS, Singh S, Vinod, Dumka UC, Pant P (2009) Spatial distribution of aerosol black carbon over India during pre-monsoon season. Atmos Environ 43(5):1071-1078. https://doi. org/10.1016/j.atmosenv.2008.11.042

Bousquet P, Ringeval B, Pison I, Dlugokencky EJ, Brunke EG, Carouge C, Chevallier F, Fortems Cheiney A, Frankenberg C, Hauglustaine DA, Krummel PB, Langenfelds RL, Ramonet M, Schmidt M, Steele LP, Szopa S, Yver C, Viovy N, Ciais P (2011) Source attribution of the changes in atmospheric methane for 2006-2008. Atmos Chem Phys 11:3689-3700. https://doi.org/10.5194/acp-11-3689-2011

Cros B, Delmas R, Nganga D, Clairac B, Fontan J (1988) Seasonal trends of ozone in equatorial Africa: experimental evidence of photochemical formation. J Geophys Res 93(D7):8355-8366. https://doi.org/ 10.1029/JD093iD07p08355

David LM, Nair PR (2011) Diurnal and seasonal variability of surface ozone and NOx at a tropical coastal site: association with mesoscale and synoptic meteorological conditions. J Geophys Res 116(D10303):1-16. https://doi.org/10.1029/2010JD015076

Draxler RR (1999) HYSPLIT4 user's guide. NOAA Tech. Memo. ERL ARL-230, NOAA Air Resources Laboratory, Silver Spring

Draxler RR, Hess GD (1998) An overview of the HYSPLIT_4 modelling system of trajectories, dispersion, and deposition. Aust Meteor Mag 47:295-308

Dutkiewicz VA, Alvi S, Ghauri BM, Choudhary MI, Husain L (2009) Black carbon aerosols in urban air in South Asia. Atmos Environ 43(10):1737-1744. https://doi.org/10.1016/j.atmosenv.2008.12.043
Fadnavis S, Beig G, Buchunde P, Ghude SG, Krishnamurti TN (2011) Vertical transport of ozone and $\mathrm{CO}$ during super cyclones in Bay of Bengal as detected by Tropospheric Emission Spectrometer. Environ Sci Pollut Res 18:301-315. https://doi.org/10.1007/ s11356-010-0374-3

Fishman J, Seiler W (1983) Correlative nature of ozone and carbon monoxide in the troposphere: implications for the tropospheric ozone budget. J Geophys Res 88(C6):3662-3670. https://doi.org/10. 1029/JC088iC06p03662

Gaur A, Tripathi SN, Kanawade VP, Tare V, Shukla SP (2014) Four-year measurements of trace gases $\left(\mathrm{SO}_{2}, \mathrm{NO}_{\mathrm{x}}, \mathrm{CO}\right.$ and $\left.\mathrm{O}_{3}\right)$ at an urban location, Kanpur, in Northern India. J Atmos Chem 71:283-301. https://doi.org/10.1007/s10874-014-9295-8

Ghosh D, Sarkar U (2016) Analysis of the photochemical production of ozone using Tropospheric ultraviolet-visible (TUV) radiation model in an Asian megacity. Air Qual Atmos Health 9:367-377. https:// doi.org/10.1007/s11869-015-0346-3

Ghosh D, Midya SK, Sarkar U, Mukherjee T (2015) Variability of surface ozone with cloud coverage over Kolkata, India. J Earth Syst Sci 124: 303-319. https://doi.org/10.1007/s12040-015-0543-3

Ghude SD, Beig G, Kulkarni PS, Kanawade VP, Fadnavis S, Remedios JJ, Kulkarni SH (2011) Regional CO pollution over the Indian subcontinent and various transport pathways as observed by MOPITT. Int J Remote Sens 32(21):6133-6148. https://doi.org/10.1080/ 01431161.2010 .507796

Giglio L, Descloitres J, Justice CO, Kaufman Y (2003) An enhanced contextual fire detection algorithm for MODIS. Remote Sens Environ 87:273-282. https://doi.org/10.1016/S0034-4257(03) 00184-6

Giglio L, Schroeder W, Justice CO (2016) The collection 6 MODIS active fire detection algorithm and fire products. Remote Sens Environ 78:31-41. https://doi.org/10.1016/j.rse.2015.08.032

Girach IA, Nair PR (2014) Carbon monoxide over Indian region as observed by MOPITT. Atmos Environ 99:599-609. https://doi.org/10. 1016/j.atmosenv.2014.10.019

Girach IA, Nair PR, Ojha N, Sahu LK (2020) Tropospheric carbon monoxide over the northern Indian Ocean during winter: influence of inter-continental transport. Clim Dyn 54:5049-5064. https://doi.org/ 10.1007/s00382-020-05269-4

Huang X, Ding A, Gao J, Zaeng B, Zhou D, Qi X, Tang R, Ren C, Nie W, Chi X, Wang J, Xu Z, Chen L, Li Y, Che F, Ni P, Wang H, Tong D, Qin W, Cheng W, Liu W, Fu Q, Chai F, Davis JS, Zhang Q, He K (2020) Enhanced secondary pollution offset reduction of primary emissions during COVID-19 lockdown in China. Natl Sci Rev. https://doi.org/10.1093/nsr/nwaa137

Jain S, Sharma T (2020) Social and travel lockdown impact considering coronavirus disease (COVID-19) on air quality in megacities of India: present benefits, future challenges and way forward. Aerosol Air Qual Res 20:1222-1236. https://doi.org/10.4209/aaqr. 2020.04.0171

Jain S, Aggarwal P, Sharma P, Kumar P (2016) Vehicular exhaust emissions under current and alternative future policy measures for megacity Delhi, India. J Transp Health 3:404-412. https://doi.org/10. 1016/j.jth.2016.06.005

Jang E, Do W, Park G, Kim M, Yoo E (2017) Spatial and temporal variation of urban air pollutants and their concentrations in relation to meteorological conditions at four sites in Busan. South Korea, Atmos Pollut Res 8:89-100. https://doi.org/10.1016/j.apr.2016.07.009

Kavitha M, Nair PR, Girach IA, Aneesh S, Sijikumar S, Renju R (2018) Diurnal and seasonal variations in surface methane at a tropical coastal station: role of mesoscale meteorology. Sci Total Environ 631-632: 1472-1485. https://doi.org/10.1016/j.scitotenv.2018.03.123 
Kompalli SK, Babu S, Moorthy KK, Manoj MR, Kumar NVPK, Shaeb HB, Joshi AK (2014) Aerosol black carbon characteristics over Central India: temporal variation and its dependence on mixed layer height. Atmos Res 147-148:27-37. https://doi.org/10.1016/j. atmosres.2014.04.015

Lal S, Naja M, Subbaraya BH (2000) Seasonal variations in surface ozone and its precursors over an urban site in India. Atmos Environ. 34:2713-2724. https://doi.org/10.1016/S13522310(99) 00510-5

Lal S, Venkataramani S, Chandra N, Cooper OR, Brioude J, Naja M (2014) Transport effects on the vertical distribution of tropospheric ozone over western India. J Geophys Res Atmos 119:10012-10026. https://doi.org/10.1002/2014JD021854

Mahapatra PS, Panda S, Walvekar PP, Kumar R, Das T, Gurjar BR (2014a) Seasonal trends, meteorological impacts, and associated health risks with atmospheric concentrations of gaseous pollutants at an Indian coastal city. Environ Sci Pollut Res 21:11418-11432. https://doi.org/10.1007/s11356-014-3078-2

Mahapatra PS, Panda S, Das N, Rath S, Das T (2014b) Variation in black carbon mass concentration over an urban site in the eastern coastal plains of the Indian sub-continent. Theor Appl Climatol 117:133147. https://doi.org/10.1007/s00704-013-0984-z

Mahapatra PS, Sinha PR, Boopathy R, Das T, Mohanty S, Sahu SC, Gurjar BR (2018) Seasonal progression of atmospheric particulate matter over an urban coastal region in peninsular India: role of local meteorology and long-range transport. Atmos Res 199:145-158. https://doi.org/10.1016/j.atmosres.2017.09.001

Mahapatra PS, Kumar R, Mallik C, Panda S, Sahu SC, Das T (2019) Investigation of a regional ozone reduction event over eastern India by integrating in situ and satellite measurements with WRF-Chem simulations. Theor Appl Climatol 137:399-416. https://doi.org/10. 1007/s00704-018-2593-3

Mahata KS, Rupakheti M, Pandey AK, Bharadwaj P, Naja M, Singh A, Mues A, Cristofanelli P, Pudasainee D, Bonasoni P, Lawarence MG (2018) Observation and analysis of spatiotemporal characteristics of surface ozone and carbon monoxide at multiple sites in the Kathmandu Valley, Nepal. Atmos Chem Phys 18:14113-14132. https://doi.org/10.5194/acp-18-14113-2018

Mallik C, Lal S, Venkataramani S (2015) Trace gases at a semi-arid urban site in western India: variability and inter-correlations. J Atmos Chem 72:143-164. https://doi.org/10.1007/s10874-015-9311-7

Mallik C, Tomsche L, Bourtsoukidis E, Crowley JN, Derstroff B, Fischer H, Hafermann S, Hüser I, Javed U, Kebel S, Lelieveld J, Martinez M, Meusel H, Novelli A, Phillips GJ, Pozzer A, Reiffs A, Sander R, Taraborrelli D, Sauvage C, Schuladen J, Su H, Williams J, Harder H (2018) Oxidation processes in the eastern Mediterranean atmosphere: evidence from the modelling of HOx measurements over Cyprus. Atmos Chem Phys 18:10825-10847. https://doi.org/10. 5194/acp-18-10825-2018

Mallik C, Mahapatra PS, Kumar P, Panda S, Boopathy R, Das T, Lal S (2019) Influence of regional emissions on $\mathrm{SO}_{2}$ concentrations over Bhubaneswar, a capital city in eastern India downwind of the Indian $\mathrm{SO}_{2}$ hotspots. Atmos Environ 209:220-232. https://doi.org/10. 1016/j.atmosenv.2019.04.006

Nair PR, Chand D, Lal S, Modh KS, Naja M, Paremeswaran K, Ravindran S, Venkataramani S (2002) Temporal variations in surface ozone at Thumba $(8.61 \mathrm{~N}, 771 \mathrm{E})$ a tropical coastal site in India. Atmos Environ 36:603-610. https://doi.org/10.1016/S13522310(01)00527-1

Nishanth T, Satheesh Kumar MK, Valsaraj KT (2012) Variations in surface ozone and $\mathrm{NO}_{\mathrm{x}}$ at Kunnur: a tropical, coastal site in India. $\mathrm{J}$
Atmos Chem 69:101-126. https://doi.org/10.1007/s10874-0129234-5

Rana A, Jia S, Sarkar S (2019) Black carbon aerosol in India: a comprehensive review of current status and future prospects. Atmos Res 218:207-230. https://doi.org/10.1016/j.atmosres.2018.12.002

Resmi CT, Nishanth T, Satheesh Kumar MK, Manoj MG, Balachandramohan M, Valsaraj KT (2020) Air quality improvement during triple-lockdown in the coastal city of Kannur, Kerala to combat Covid-19 transmission. PeerJ 8:9642. https://doi.org/10.7717/ peerj. 9642

Saunois M, Jackson RB, Bousquet P, Poulter B, Canadell JG (2016) The growing role of methane in anthropogenic climate change. Environ Res Lett 11:120207. https://doi.org/10.1088/1748-9326/11/12/ 120207

Seinfeld JH, Pandis SN (1998) Atmospheric chemistry and physics: from air pollution to climate changes. Wiley, New York, p 1326

Sharma M, Jain S, Lamba BY (2020a) Epigrammatic study on the effect of lockdown amid COVID-19 pandemic on air quality of most polluted cities of Rajasthan (India). Air Qual Atmos Health. https://doi. org/10.1007/s11869-020-00879-7

Sharma S, Zhang M, Anshika Gao J, Zhang H, Kota SH (2020b) Effect of restricted emissions during COVID-19 on air quality in India. Sci Total Environ 728:138878. https://doi.org/10.1016/j.scitotenv.2020. 138878

Singh RP, Chauhan A (2020) Impact of lockdown on air quality in India during COVID-19 pandemic. Air Qual Atmos Health 13:921-928. https://doi.org/10.1007/s11869-020-00863-1

Stein AF, Draxler RR, Rolph GD, Stunder BJB, Cohen MD, Ngan F (2015) NOAA's HYSPLIT atmospheric transport and dispersion modeling system. Bull Amer Meteor Soc 96:2059-2077. https:// doi.org/10.1175/BAMS-D-14-00110.1

Talukdar S, Jana S, Maitra A, Gogoi MM (2015) Characteristics of black carbon concentration at a metropolitan city located near land-ocean boundary in Eastern India. Atmos Res 153:526-534. https://doi.org/ 10.1016/j.atmosres.2014.10.014

Tiwari S, Srivastava AK, Parmita P, Srivastava KM, Attri SD (2013) Diurnal and seasonal variations of black carbon and PM2. 5 over New Delhi, India: Influence of meteorology. Atmos Res 125-126: 50-62. https://doi.org/10.1016/j.atmosres.2013.01.011

Tiwari S, Dahiya A, Kumar N (2015) Investigation into relationships among $\mathrm{NO}, \mathrm{NO}_{2}, \mathrm{NOx}, \mathrm{O}_{3}$, and $\mathrm{CO}$ at an urban background site in Delhi, India. Atmos Res 157:119-126. https://doi.org/10.1016/j. atmosres.2015.01.008

Tobias A, Carnerero C, Reche C, Massague J, Via M, Mingullion MC, Alastuey A, Querol X (2020) Changes in air quality during the lockdown in Barcelona (Spain) one month into the SARS CoV2epidemic. Sci Total Environ 726:138540. https://doi.org/10.1016/ j.scitotenv. 2020.138540

Vaishya A, Singh P, Rastogi S, Babu SS (2017) Aerosol black carbon quantification in the central Indo-Gangetic Plain: seasonal heterogeneity and source apportionment. Atmos Res 185:13-21. https://doi. org/10.1016/j.atmosres.2016.10.00

Venkataraman C, Habib G, Fernandez E, Miguel AH, Friedlander SK (2005) Residential biofuels in South Asia: carbonaceous aerosol emissions and climate impacts. Science 307:1454-1456. https:// doi.org/10.1126/science.1105675

Xie M, Zhu K, Wang T, Chen P, Han Y, Li S, Zhuang B, Shu L (2016) Temporal characterization and regional contribution to $\mathrm{O}_{3}$ and $\mathrm{NO}_{\mathrm{x}}$ at an urban and a suburban site in Nanjing, China. Sci Total Environ 551-552:533-545. https://doi.org/10.1016/j.scitotenv.2016.02.047

Xu K, Cui K, Young LH, Hsieh YK, Wang YF, Zhang J, Wan S (2020) Impact of the COVID-19 event on air quality in central China. 
Aerosol Air Qual Res 20:915-929. https://doi.org/10.4209/aaqr. 2020.04.0150

Yadav R, Sahu LK, Beig G, Jaaffrey SNA (2016) Role of long-range transport and local meteorology in seasonal variation of surface ozone and its precursors at an urban site of India. Atmos Res. 176177:96-107. https://doi.org/10.1016/j.atmosres.2016.02.01

Yen MC, Peng CM, Chen TC, Chen CS, Lin NH, Tzeng RY, Lee YA, Lin CC (2013) Climate and weather characteristics in association with the active fires in northern Southeast Asia and spring air pollution in Taiwan during 2010 7-SEAS/Dongsha experiment. Atmos Environ 78:35-50. https://doi.org/10.1016/j.atmosenv.2012.11.015
Zhao S, Yu Y, Yin D, He J, Liu N, Qu J, Xiao J (2016) Annual and diurnal variations of gaseous and particulate pollutants in 31 provincial capital cities based on in situ air quality monitoring data from China National Environmental Monitoring Center. Environ Int 86: 92-106. https://doi.org/10.1016/j.envint.2015.11.003

Zheng S, Singh RP, Wu Y, Wu C (2017) A Comparison of Trace Gases and Particulate Matter over Beijing (China) and Delhi (India). Water Air Soil Pollut 228:181. https://doi.org/10.1007/s11270-017-3360-2

Publisher's note Springer Nature remains neutral with regard to jurisdictional claims in published maps and institutional affiliations. 